\title{
Difficulties and Countermeasures of Current Postgraduate Talents Training in Environmental Art Design Based on Sustainable Development
}

\author{
Shuzhen Zou, Mengyu Sun, Weili Wang, Yu Zeng \\ Jiangxi Science and Technology Normal University \\ Nanchang, Jiangxi, 330000, China
}

\begin{abstract}
In recent years, with the expansion of postgraduate education scale in China, the problem of difficulty in adapting the quality of talents training has become increasingly prominent. This work took postgraduate students of environmental art design in China as the research object, combined the concept of sustainable development with talents training, exploring root causes of talents training dilemma and proposed feasible improvement measures. Through research and analysis, changing teaching concepts, optimizing teaching system, updating teaching methods and improving scientific research ability are important measures to optimize talents training program and improve the quality of talents training, which is significant to promote the curriculum reform of environmental art design in China and cultivate postgraduate talents for environmental art design with sustainable development.
\end{abstract}

Keywords-Sustainable development; Environmental art design; Talents training; Curriculum reform

\section{INTRODUCTION}

Postgraduate talents act as an outstanding backup force for China's future builders. Although the major of environmental art design starts late in China, the number of applicants annually is rising, which means that this major has development potential in contemporary society. Acting as a characteristic major that is urgently needed by the current social environment and national conditions, it has an inestimable effect on China's urban construction and ecological transformation. Combining sustainable development with postgraduate talents training majored in environmental art has its own historical significance [1]. Therefore, how to conduct postgraduate talents training of environmental art design based on the current educational environment in China is a problem worth considering deeply by every educator.

\section{SUStainABlE DEVELOPMENT AND TALENTS TRAINING OF ENVIRONMENTAL ART DESIGN}

According to relevant literature, most authors study problems existing in the current teaching process and teaching methods from the aspect of talents training reform, but few studies how to combine sustainable development concept with postgraduate talents training reform of environmental art design. Sustainable development is the concept that closely follows the pace of the times and national policy, therefore students, especially students majored in environmental art design should accept such theoretical education. Design majors aim at cultivating students' creative thinking to realize the ability of postgraduate students in thinking, application and research, which has strong applicability. Obviously, current research is extremely insufficient. Therefore, applying sustainable development theory in cultivating the creative thinking of graduate students in environmental art design is not only conducive to enriching and deepening the contents of case teaching but also helps to improve the effect of case teaching in environmental art design, which is an inevitable trend of teaching methods reform.

Contemporary postgraduate students of environmental art design undertake the tasks of domestic urban construction, landscape optimization and theoretical research. Innovative thinking ability, as well as good practice and theoretical level, are important standards for measuring their professional quality. The application of sustainable development theory and innovative training of postgraduate talents has far-reaching positive significance.

\section{CurRent Postgraduate TALENTS Training PREDICAMENT OF ENVIRONMENTAL ART DESIGN IN CHINA}

Nowadays, some developed countries have set their own development goals for the globalization of design education based on their actual domestic conditions. Driving the development of design education with sustainable talents training and communicating with the international community to enhance international competitiveness is also the trend of design majors and postgraduate talents training in China [2]. However, there still exists some predicament in the graduate education of environmental art design in colleges and universities of China.

\section{A. Lagging teaching management method and the single training mode}

Most colleges and universities in China have not yet established a sound management mechanism for postgraduate talents training, but often use outdated training programs, so that professors still dominate in teaching knowledge to postgraduate students of the environmental art design, which shows the tendency of single talents training mode. Lacking correct guidance of teachers has caused postgraduate students to lose their dominant position in the process of training. Their 
self-learning spirit and personality are constrained, so it is difficult to fully mobilize their enthusiasm for learning, and it is impossible to transform classroom teaching into a process of self-accepting professional knowledge as well as summing up and innovating [2].

\section{B. Narrow coverage of professional courses and limited development space}

From the perspective of colleges and universities, the general curriculum setting of postgraduate degree programs in environmental art design is mainly reflected in professional theory courses such as design history and design introduction but rarely involved in social humanities, resulting in narrow knowledge coverage and shallow extent. Students lack a basic understanding of contemporary theoretical thoughts, and it hinders the deep exploration of design and creation concepts [3].

From the perspective of students, most postgraduate students majored in environmental art design have problems of low comprehensive quality and weak foundation in public course. They are even not familiar with the knowledge of design management, construction management and design communication, which are closely linked to their major. As a result, their academic development is limited [4]. Taking a university in China as an example, courses for graduate students of environmental art design in the first year are shown in Table I.

TABLE I. A FRESHMAN COURSES FOR GRADUATE STUDENTS IN ENVIRONMENTAL ART AND DESIGN IN A UNIVERSITY IN CHINA

\begin{tabular}{|c|c|c|c|c|c|}
\hline \multirow[b]{2}{*}{$\begin{array}{l}\text { Curriculum } \\
\text { nature }\end{array}$} & \multicolumn{3}{|c|}{ Degree course } & \multicolumn{2}{|c|}{ Non-degree course } \\
\hline & Public class & Major basic class & Major core class & Major direction course & $\begin{array}{c}\text { Quality education } \\
\text { course }\end{array}$ \\
\hline \multirow{4}{*}{ Course title } & English & $\begin{array}{l}\text { Modeling } \\
\text { foundation }\end{array}$ & $\begin{array}{l}\text { Academic paper } \\
\text { writing }\end{array}$ & $\begin{array}{c}\text { the methodology of the } \\
\text { environmental art } \\
\text { design }\end{array}$ & $\begin{array}{l}\text { Chinese traditional } \\
\text { culture }\end{array}$ \\
\hline & Major English & Design foundation & $\begin{array}{l}\text { Postmodern art } \\
\text { design }\end{array}$ & $\begin{array}{c}\text { Research on the } \\
\text { Building Decoration } \\
\text { Materials }\end{array}$ & Music therapy \\
\hline & $\begin{array}{l}\text { Marxism and Social } \\
\text { Science Methodology }\end{array}$ & & Design aesthetics & & \\
\hline & $\begin{array}{c}\text { Theory and practice of } \\
\text { Socialism with Chinese } \\
\text { characteristics }\end{array}$ & & & & \\
\hline
\end{tabular}

\section{Lack of design thinking and innovation ability}

Application of innovative thinking and logical thinking is one of the important criteria to evaluate whether environmental art design postgraduate is excellent or not. For a long time, environmental art design has not established a systematic and integrated theoretical research system. There is no distinction of teaching and talents training between undergraduate education and postgraduate education. Using the training mechanism that is all of a piece has limited investment in design thinking expansion and design method application, which cannot meet postgraduates' learning demand for selective and automatic contents [2].

Compared with developed countries, postgraduates of environmental art design in China generally show weak design and innovation ability, and they are difficult to present environmental art design works with high artistic and technical value, which is closely related to the lack of innovative thinking training of design and the neglect of logical thinking training.

\section{Incomplete understanding of scientific research and valueless results}

Nowadays, since the way of using intuition and inspiration as the basis has been confirmed to be unacceptable, development of environmental art design is not only a matter of function and form, but needs the support of science. Scientific research and practice are two sides of the same coin, but the postgraduate training in most colleges and universities has the behavior of separating scientific research from practice. Postgraduate students in this kind of educational environment tend to jump into the trap of acting blindly and lack professional knowledge as well as independent perspectives. What's more, equating the academic research to papers, which include many seemingly correct but actually useless words have had a negative impact on the long-term healthy development of the industry, resulting in a social misunderstanding of this major [4].

\section{TRAining STRATEgIES FOR POSTGRAdUATE TALENTS OF ENVIRONMENTAL ART DESIGN UNDER THE PERSPECTIVE OF SUSTAINABLE DEVELOPMENT}

Based on the above-mentioned problems and combined with high-quality examples and achievements of postgraduate education in design both at home and abroad, following suggestions are made to integrate the theory of sustainable development into the postgraduate talents training of environmental art design.

\section{A. Transforming teaching concepts}

Traditional education concept of environmental art design in China has a biased view of favoring knowledge over ability, profession over quality and inheritance over innovation, which seriously hinders the postgraduate talents training of this major. Environmental art design belongs to an open major. With the development of the times, its methods, contents and theories do not show strong adaptability, which inevitably requires postgraduate students of the environmental art design to develop in a pluralistic way [5].

Therefore, in order to cultivate talents who can meet requirements of the development of the times and guide the 
sustainable development of the society, it is necessary to establish a new concept of education, teaching and talents. Based on inheriting excellent traditional educational ideas, it is necessary to "integrate business training with quality education, knowledge transmission with ability training and education teaching with scientific research" in the training of postgraduate talents [5].

\section{B. Optimizing curriculum teaching system}

Since environmental art design emphasizes the individuality and advertises difference, there is no formula for it. However, it is different from conventional art creation, since it must pay attention to practice and application, so as to provide service for people's quality of life.

The curriculum of environmental art design should emphasize pertinence, which should start from professional theoretical research and social practice, and at the same time pay equal attention to design modules and management modules. Theoretical teaching curriculum of postgraduate students should adopt the thesis seminar curriculum, independent reading research course and mentorship seminar curriculum, which are both prescriptive and flexible. The academic seminar can also be held regularly to change the classroom from teaching and listening to exchanging experience, sharing information, observing results, and critically brainstorming [6]. Instructors can achieve role transition from infusion to guidance, while students can realize the comprehensive transition from passive acceptance of knowledge to active learning and independent innovation.

In addition, professional practice curriculum can adopt the method of either going out (team implanted enterprises) or calling in (inviting enterprises to enter school to establish design and research institutions). Driving design practice with projects can create opportunities for students to directly integrate with design enterprises, production enterprises and industry associations. Students should also be supported to test the theory through practice, transform design blueprint into a realistic work, and communicate with experts from different professions in the front line. Schools can also support instructors to work in related companies or associations, or even create their own design and manufacturing companies, so as to obtain first-hand information and feedback for teaching and research.

\section{Updating the teaching method}

The environmental art design is a professional discipline with high practicality and high operability. Because of its specialty, it requires educators and postgraduate students to construct a reasonable and effective teaching relationship, so that study of professional curriculum and practice behavior of postgraduate talents can be effectively combined in the actual design. Updating teaching methods and adopting more interactive teaching methods that focus on behavioral training are conducive to improving the enthusiasm of professional talents. Postgraduate students should be guided to pay attention to both "listening" and "practice" and encouraged to strengthen their understanding of professional knowledge and gain professional practical ability through practice.
As a milestone in art design education, Bauhaus in Germany takes harmonious development of art, craftsmanship and technology as its central gist, which has laid the foundation of design education and created a thriving development of art design. Teachers in Bauhaus are also excellent designers and architects in the industry. They not only teach students basic curriculum such as painting, but also teach students traditional craftsmanship, modern manufacturing techniques and material characteristics in school studios, so they are also known as the "studio instructor". The "studio instructor" teaching system in Bauhaus can be imitated in the environmental art design teaching in China. Through teachers' teaching by words and deeds in the studio, which should be provided by schools, the outdated educational method of "learning without doing" can be improved [2].

\section{Enhancing scientific research and practical ability}

Scientific research ability is not only an essential ability for postgraduate talents training, but also an important way to enhance the competitiveness of postgraduate students and strengthen discipline building capacity. With the perfection of science and technology, it is difficult for postgraduate students to overcome academic problems and obtain important progress and discoveries by themselves alone.

As the educator, Tao Xingzhi said: "A vibrant, stable, harmonious and healthy environment has a wide range of educational functions". Forming a team of postgraduate students is the dual need for professional teaching and overcoming scientific research, which is of great significance to the cultivation of environmental art design postgraduates in colleges and universities. The team can guarantee the continuity of research topics and avoid blindness and randomness of the topic. Carrying out research and practice in a team is conducive to the benign interaction among postgraduate students, which helps form a mentor relationship among postgraduate students of different grades. Senior grade students can use their accumulated experience to form a step and thrust for the latecomers, contributing to the overall advancement [7]. Building an innovative team can not only improve the overall scientific research level of postgraduate students, but also provide opportunities to improve their professional levels for those who are still in the tender stage.

\section{CONCLUSION}

What environmental art design studies and tries to solve is the problem of harmonious coexistence among city, ecology and human. Its content includes subjective artistic creation and objective living space, which are both a rational scientific view and a perceptual artistic view. The environmental art designer should be a bridge that links society, culture and ecology organically, and improves the living environment of human beings with rational thoughts, sustainable ecological design principles and artistic treatment. Therefore, requirements for postgraduate students of environmental art design are comprehensive. What the environmental art design cultivates should be the coordinator and reformer of the highly unified environmental relationship between technology and art. Strengthening the practical teaching of postgraduate students, broadening the scope of professional peripheral knowledge and 
improving the faculty and curriculum structure can achieve the sustainable development of postgraduate talents in environmental art design.

\section{ACKNOWLEDGMENT}

Research Project on Teaching Reform of Degree and Postgraduate Education in Jiangxi Science and Technology Normal University in 2017.

\section{REFERENCES}

[1] Ji Tao, Sun Dongmei. Construction of Digital Art Talents Training Mode [J]. Industry and Technology Forum, 2012 (04): 140 - 141.

[2] Wang Wei. Research on the Cultivation of Scientific Research Innovation Ability of Postgraduate Students Majored in Environmental Art Design [J]. Idea and Design, 2015 (06): 66 - 70.
[3] Jin Ke. Research on Postgraduate Education of Environmental Art Design Major - Taking the Teaching and Creation Practice of Environmental Art Design Postgraduate Students at Southwest University as an Example [J]. Art Observation, 2012(12): 88 - 89.

[4] Li Wenhua. Exploration of the Innovative Training Mode of Postgraduate Students in Environmental Art Design Direction [J]. Journal of Shandong University of Arts and Design, 2012 (03): 10 - 12.

[5] Ma Yanxiang, Cai Zhonghong. Research on the Reform and Trend of Talents Training Mode in Colleges and Universities [J]. Journal of Lanzhou Jiaotong University, 2009 (05): 139 - 142.

[6] Xu Qing, Ling Changming. Research on Postgraduate Training Mode Based on Comprehensive Quality Improvement [J]. University Education, 2017(01): 165 - 167.

[7] Le Wuyang. Research on the Party Setting Mode of Postgraduate Students in Colleges and Universities [J]. Off-campus Education in China: Late Edition, 2012 (12): 21 + 128. 